\title{
Principles of Textual Rhetoric in CakCuk Discourse
}

\author{
Foriyani Subiyatningsih \\ Balai Bahasa JawaTimur, Indonesia \\ E-mail: foriyanis@yahoo.com
}

\begin{abstract}
This research aims to study how the creator of CakCuk creates language based on the principles and maxims of textual rhetoric in CakCuk designs. The data was collected using a method of observation, with a basic technique of recording followed by a technique of note-taking. The data analysis used a method of distribution, comparison, and contextual identity. The results of this study show that CakCuk discourse is a product of the language creativity of its creator through the utilization of principles or maxims of textual rhetoric. The key to this creativity is the creator's ability to use maxims in order to achieve efficiency, clarity, effectiveness, and attractiveness in the text. The motivation underlying the choice of principles/ maxims is: (i) the principle of processability in order to determine the main focus and weighting of the text; (ii) the principle of clarity in order to make the message clear; (iii) the principle of economy in order to keep the text as short as possible; (iv) the principle of expressiveness in order to make the text effective.
\end{abstract}

Keywords: product design; language creativity; CakCuk; principle of textual rhetoric

\section{INTRODUCTION}

CakCuk is a product of the creative industry from the subsector of fashion and design which produces a variety of souvenirs, such as t-shirts, gifts, and accessories. One aspect of CakCuk that is interesting to study linguistically is the use of language, since this is the most important aspect in the creation of the product design. The design process essentially takes into account the aspects of function and aesthetic, as well as various other aspects that are derived from ideas, brain-storming, and other previous designs. Designs that involve the use of language become interesting when the arrangement of the language itself can be understood as a text (textual discourse) which produces numerous different interpretations in terms of linguistic perspective.

In terms of functionality, discourse is the totality of transaction and is considered as an attempt to convey the power of discourse to the reader. Textual power is pragmatic power which explains clearly the speaker's intention about the condition/ final objective to be achieved. In line with this functionality, CakCuk discourse is understood to be the result of linguistic communication (=speech) of the transactions that occur on three different levels, namely (1) the interpersonal transaction, or discourse; (2) the ideational transaction, or delivery of the message (message-transmission); and (3) the textual transaction, or text. These transactions are arranged in a manner such that CakCuk discourse embraces the message and the message embraces the text. Thus, CakCuk discourse shows a series of transactions. Each transaction has a different purpose from the overall textual organization. The interpersonal transaction aims to divert the function of (certain) language, as a tool for revealing the creator's motives and influencing the attitudes and behavior of the reader. The ideational transaction aims to divert the function of language as a transmitter and interpreter of the world experience. The textual transaction aims to divert the function of language as a tool for constructing a text.

The use of language elements in CakCuk designs, whatever form they may take, is essentially a form of discourse. As stated by linguists, the meaning of discourse is the use of language in communication, 
both oral and written (Halliday and Hassan, 1979; Widd 1981; Brown and Yule, 1983). The use of language in written form is discourse that is referred to as a text (speech). A text (speech) consists of words or sentences. Thus, a text also consists of different meanings. However, a text is also a unit of meaning. The meaning of a text can be understood through the communication situation that accompanies or supports the speech (context) and the meaning that is agreed upon by the language users in the communication process. In the design of CakCuk products, the context of a text may be in the form of an icon, image, diagram, and so on.

In natural communication, the speaker articulates speech with the intention of communicating something to the listener and hopes that the listener understand the words conveyed. Moreover, in interpersonal communication, there is a kind of cooperative principle which is followed by the speaker and the listener so that the communication process runs smoothly (Wijana, 1995:33--35). The speaker tries to convey his speech in a way that is relevant to the context, clear, easy to understand, compact, concise, and always straight forward. According to studies in pragmatics, when a deviation occurs, there are certain implications that the speaker wishes to achieve. In CakCuk discourse, the potential for deviation in the principle of rhetoric is likely to occur for a variety of reasons, such as limitations of the media, humorous effect (comic effect), aesthetic effect, or other effects.

Rhetoric, in the traditional sense (in certain historical traditions), is defined as the art of using language skills for the purpose of persuasion, literature, or giving a speech. In its general understanding, rhetoric, as stated by Leech (1993:22), is effective in the use of language in communication, not just limited to formal and planned conversations, but also including everyday conversation. The term rhetoric focuses on the goal-oriented speech situation, and in this situation the speaker uses language with the aim of producing a certain effect in the mind of the listener.

Rhetoric can be understood as a set of conversational principles that are related by their functions. Halliday (1979:57--79) distinguishes rhetoric into two types, namely interpersonal rhetoric and textual rhetoric. Each type of rhetoric consists of a set of principles, such as the cooperative principle and the principle of courtesy. These principles also consist of a set of maxims (Grice's terminology (1981)). It is more appropriate to observe the use of language in CakCuk designs from the perspective of textual rhetoric because the textual aspect is much more prominent in the use of language in this context.

Textual rhetoric has been described by Slobin (1975:1--30) as a device consisting of a number of principles that serve as a pragmatic factors which control the text. Slobin divides this textual rhetoric device into four principles: (1) try to ensure that the text can be processed within the time limit of human capability; (2) try to ensure that the text is clear; (3) try to keep the text short and easily understood; and (4) try to make the text expressive.

In line with Slobin, Leech (1993:96--106)) also describes four principles of textual rhetoric: (1) the principle of processability, (2) the principle of clarity, (3) the principle of economy, and (4) the principle of expressiveness. The principle of processability means that the text is presented in such a way that it is easy for the audience to decode the message in time. Theoretically, the text and message are different because a text is linear and time is limited, so that in the process to decode the message, we often have to determine (a) how to divide the message into units; (b) how many subordination levels there are and how important is the role of each of the units; and (c) how to arrange the units of the message. The principle of clarity is divided into two maxims, namely (a) the maxim of clarity and (b) the maxim of ambiguity. The principle of economy ensures that the text is kept short and easily understood. This principle has the maxim of reduction. The processes contained within the scope of reduction are (a) pronominalization, (b) substitution (replacement), and (c) ellipsis (deletion). The principle of expressiveness requires the text to mimic aspects of the message.

From some of the principles and textual rhetoric maxims mentioned above, there are a number of maxims which tend to move towards the same goal, namely the final focus and final weight. There are also several maxims which tend to compete or conflict with each other, namely the principle of clarity and the principle of economy. In language use, the application of rhetorical maxims is determined by the desired intention or effect that the speaker wishes to achieve.

The aim of this study is to explain linguistically CakCuk discourse as a form of real implementation of language potential in the creative industry, especially related to the creation of product design. Language use in CakCuk products is studied from the perspective of pragmatics, which consider the principles of textual rhetoric in the textual arrangement of product designs. The research was conducted in three phases of activity, 
namely data collection, data analysis, and presentation of the results of the data analysis. The data collection was conducted using methods which referred to the basic technique of recording and followed by note-taking (Sudaryanto:1993). The data analysis was conducted using methods of comparison and contextual identity (Sudaryanto:1992, 1985, 1990; Rani 2006:195-199). The data in this research is lingual in nature. The research source included the various kinds of souvenirs produced by CakCuk that contain the application of language.

Previous research that is relevant to this current study includes research by Wijana (2003:1-15), presented in his Inaugural Speech on the occasion of his appointment as Professor in the Faculty of Humanities Universitas Gadjah Mada, which explains that the discourse of Dagadu is strongly associated with famous slang expressions that are familiar to Jogjakarta society. The concept of slang includes a number of irregularities, such as phonological and grammatical elements, differences between form and meaning, reinterpretation of words and phrases, and other forms of improper language use.

The above explanation led the author to the assumption that a study of CakCuk discourse from a linguistic perspective with a pragmatic approach was necessary in order to produce an understanding of the discourse genre as an aspect of language.

\section{APPLICATION OF PRINCIPLES OF TEXTUAL RHETORIC IN CAKCUK DISCOURSE}

The application of principles of textual rhetoric in CakCuk discourse refers to the opinion of Leech (1993:96--106), namely that stylistic selection in language use, both spoken and written, is regulated by principles of textual rhetoric. Textual rhetoric can be categorized into four principles, namely (a) the principle of processability, (b) the principle of clarity, (c) the principle of economy, and (d) the principle of expressiveness.

The following sub-sections present an explanation of how the application of these four principles of textual rhetoric determine the stylistic form of the text in CakCuk.

\section{Principle of Processability in CakCuk Discourse}

In determining the stylistic form of the text in CakCuk, this principle is divided into end-focus and endweight maxims. The end-focus maxim divides the message into units of meaning. Each unit is divided or separated by a space, or by punctuation such as a comma, semicolon, dash, slash, dot, etc. See data (1) and (2) below.

(1) Global lawannya Lokal Globalisasi lawannya Lokalisasi Jakarta, Bali, Batam, Singapura, Kuala Lumpur boleh berlomba-lomba menuju globalisasi SURABAYA ....tetep jadi lokalisasi aja

Global versus Local Globalization versus Localization Jakarta, Bali, Batam, Singapore, Kuala Lumpur may compete towards globalization SURABAYA .. stays local

\section{(2) KBRI}

Kuli BATU Republik Indonesia......Kuli batu adalah Bapak Pembangunan Indonesia sejati karena tanpa mereka, tak mungkin ada gedung sekolah, rumah sakit, mall, kantor, apartemen, dll

\section{KBRI}

Construction Labourer for the Republic of Indonesia... The construction labourer is the real Father of Construction of Indonesia because without them, there would be no schools, hospitals, malls, offices, apartments, etc.

The end-focus maxim separates the message based on its phonological structure. In data (1) there are four messages and data (2) two messages. This maxim also assigns a message unit that is focused on the end of the sentence.

The end-weight maxim regulates the syntactic structure, ensuring that the light constituent precedes the heavy constituent. Thus, in the syntactic structure of sentences in CakCuk discourse, the light constituent is generally placed on the left or at the front of the sentence, while the heavy constituent is placed on the right or at the end of the sentence. See texts (3) to (5) below.

(3) Kalau sekedar misuh saja, gak perlu pake bahasa Inggris, cintailah produk Indonesia, termasuk bahasanya, di Surabaya orang misuh pake bahasa asli, bukan bahasa asing cuk! 
If you're just swearing, there's no need to use English, love Indonesian products, including the language, in Surabaya people swear in their own language, not in a foreign language fu*k!

(4) bahkan....

Bali aja dimakan di Surabaya ada bali telor, bali tahu, bali bandeng, bali daging

bali tongkol, bali ayam, dan bali-bali lainnya

In point of fact....

even bali is eaten in Surabaya

there are bali eggs, bali tofu, bali fish, bali meat, bali tuna, bali chicken, and other bali things

(5) Bart Simpsons pernah tinggal di Surabaya lho! Pas SD dia disetrap gurunya gara-gara misuh Saya berjanji tidak akan bilang jancuk lagi Saya berjanji tidak akan bilang jancuk lagi Saya berjanji tidak akan bilang jancuk lagi Saya berjanji tidak akan bilang

Bart Simpson used to live in Surabaya yo!

At elementary school he was punished for swearing

I promise to not say fu*k again

I promise to not say fu*k again

I promise to not say fu*k again

I promise to not say

In text (3) the clause Kalau sekedar misuh saja, gak perlu pake bahasa Inggris is located at the beginning of the sentence and categorized as a light constituent. The clause cintailah produk Indonesia, termasuk bahasanya, di Surabaya orang misuh pake bahasa asli, bukan bahasa asing cuk! is a heavy constituent and located at the end of the sentence. In texts (4) and (5) the clauses Bali aja dimakan di Surabaya and Bart Simpsons pernah tinggal di Surabaya 1 ho! are both located at the front of the sentence, and are therefore referred to as light constituents. The clause ada bali telor, bali tahu, bali bandeng, bali daging, bali tongkol, bali ayam, dan bali-bali lainnya in text (4) and the clause Pas SD dia disetrap gurunya gara-gara misuh in text (5) are heavy constituents so are placed at the end of the sentence.

The heavy constituents in texts (3), (4) and (5) are the constituents that contain new information and are the primary focus of the information structure of the sentence.

\section{Principle of Clarity in CakCuk Discourse}

The principle of clarity is made up of two maxims: (a) maxim of transparency and (b) maxim of ambiguity. The transparency maxim tends to make a clear and direct relation between phonological structure and semantic structure (or between message and text), while the ambiguity maxim tends to avoid the use of ambiguous words. In the syntactic structure, clarity means that units which have a close semantic gap are also expected to have a close syntactic gap.

The data on CakCuk shows that the stylistic form of the text is varied. Some texts are formed to comply with the principle of clarity while others are formed in ways that violate it by following other principles.

\section{Stylistic Text Form Which Complies to the Principle of Clarity}

(6) HAYO! ADEEEK.....

GAK BOLEH MISUH LOH,YA!!!

huh!!!Papaku suka misuhan

tapi kalo aku misuh dimarahi...cuk!!!

\section{LISTEN! BROTHEEER...}

DON'T SWEAR YO!!!

Huh!!! My father likes swearing

But if I do it then he gets mad at me... fu*k!!!

In text (6) there is no ambiguity because the meaning of the sentence is quite clear. The interpretation of text (6) is that a father admonishes his son for swearing but the son feels that he is treated unfairly for doing the same thing that his father does, since his father likes swearing too.

On one hand, ambiguity should be avoided but on the other hand it is sometimes deliberately used for a specific purpose.

\section{Form of Clarification to Avoid Ambiguity}

(7) Iv SBY

(surabaya, maksudnya)

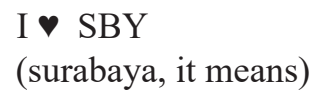

The text $I \checkmark S B Y$ in data (7) is potentially ambiguous if not followed by the clause Surabaya, maksudnya, since $S B Y$ may be misinterpreted, for 
example it may be understood to be referring to former President Susilo Bambang Yudhoyono. This clarification strategy is deliberately exploited by the creator to create a joke.

\section{Stylistic Text Form Which is Ambiguous}

(8) Lost in Dolly

Wisma Putri Lestari, Wisma Studio, Wisma Rileks, Wisma Permata Biru, Wisma Nusantara Baru, Wisma 29, Wisma Putri Ayu, Wisma Sumber Rejeki, Wisma Bangkok, Wisma Sumber Jaya, Wisma Madona Indah, Wisma Mustika, Wisma Setia Baru, Wisma Srikandi, Wisma Arumdalu, Wisma Panorama, Wisma Barbara, Wisma Madona Baru, Wisma Ratu Kembar, Wisma 25, Wisma Mamamia, Wisma Setia Asih, Wisma Tentrem, Wisma Tampomas, Wisma Harmonia, Wisma Hollywood, Wisma Jaya Indah.

\section{Lost in Dolly}

House of Putri Lestari, House of Studio, House of Rileks, House of Permata Biru, House of Nusantara Baru, House of 29, House of Putri Ayu, House of Sumber Rejeki, House of Bangkok, House of Sumber Jaya, House of Madona Indah, House of Mustika, House of Setia Baru, House of Srikandi, House of Arumdalu, House of Panorama, House of Barbara, House of Madona Baru, House of Ratu Kembar, House of 25, House of Mamamia, House of Setia Asih, House of Tentrem, House of Tampomas, House of Harmonia, House of Hollywood, House of Jaya Indah.

\section{(9) SEX IN THE CITY SURABAYA CITY NUR BUAYA}

The ambiguity in text (8) is due to the fact that the relationship between the clause lost in Dolly and the confirmative units is indistinct. This obscurity is caused by the confirmative units not forming a predicative structure. The relationship would become clear if a predicate was added before the confirmative unit, for example hilang diantara ... atau .... Consider the following sentence.

(8a) Lost in Dolly, hilang diantara Wisma Putri Lestari, Wisma Studio, Wisma Rileks, Wisma
Permata Biru, Wisma Nusantara Baru, Wisma 29, Wisma Putri Ayu, Wisma Sumber Rejeki, Wisma Bangkok, Wisma Sumber Jaya, Wisma Madona Indah, Wisma Mustika, Wisma Setia Baru, Wisma Srikandi, Wisma Arumdalu, Wisma Panorama, Wisma Barbara, Wisma Madona Baru, Wisma Ratu Kembar, Wisma 25, Wisma Mamamia, Wisma Setia Asih, Wisma Tentrem, Wisma Tampomas, Wisma Harmonia, Wisma Hollywood, atau Wisma Jaya Indah.

Lost in Dolly, lost in House of Putri Lestari, House of Studio, House of Rileks, House of Permata Biru, House of Nusantara Baru, House of 29, House of Putri Ayu, House of Sumber Rejeki, House of Bangkok, House of Sumber Jaya, House of Madona Indah, House of Mustika, House of Setia Baru, House of Srikandi, House of Arumdalu, House of Panorama, House of Barbara, House of Madona Baru, House of Ratu Kembar, House of 25, House of Mamamia, House of Setia Asih, House of Tentrem, House of Tampomas, House of Harmonia, House of Hollywood, or House of Jaya Indah.

The ambiguity in text (8) above occurs because of the author's preconceptions. The author mentions several houses with the preconception that Lost in Dolly will not be interpreted by the reader as 'missing or disappearing without a trace in Dolly', but instead it will be interpreted as 'being inside one of the houses mentioned'. This is different from text (9), in which the relationship between SEX IN THE CITY, SURA BAYA, and CITY NUR BUAYA is unclear due to the ambiguity of the sentence. This ambiguity is motivated by the author's intentions, namely that the text becomes multi interpretable and associative. The word CITY in SEX IN THE CITY can be linked associatively with the word Siti, and the word CITY in the CITY NUR BUAYA can be linked associatively with Siti Nurbaya, the main character in the novel "Siti Nurbaya".

\section{Principle of Economy in CakCuk Discourse}

The principle of economy regulates a text to be as short as possible and easy to understand. If a text can be shortened without diminishing the message itself, then the time and effort required to encode and decode it can also be minimized. The principle of economy contradicts the principle of clarity. The principle of 
economy requires the use of fewer language elements in the text without diminishing the message itself. On the contrary, the principle of clarity requires the use of more language elements in order to obtain a clearer message.

The principle of economy is very valuable to the creator of CakCuk for arranging the text economically due to limitations in the media used. It allows the creator of CakCuk to use fewer or simpler language units in the creation of the text. This principle enables the creator of CakCuk to use fewer units of language or language that is simpler when drafting a text. Data (10) to (12) show texts that are simple in character.

(10) SURABAYA

WEST JAVA INDONESIA

(11) JanCok lugas \& tegas Jan.COK

makian dan umpatan khas suroboyoan asli dari kota buaya

JanCok straightforward \& decisive Jan.COK

Swearing and insults Surabaya style originally from crocodile city

(12) Think different Apem bukan Apple Culinary from Java

Think differently

Apem is not Apple

Culinary food from Java

This principle offers the creator a choice; if a text can be made simpler without diminishing the message then it is better to do so. The principle of economy is not restricted to creating simpler texts with a clear message but also has the ability to generate power of discourse without any contextual support.

In data (13) and (14) below, the texts are simple but the messages are less clear. The ambiguity in both texts is caused by the use of ambiguous words. In data (13) the word kontol can be interpreted to mean 'crane' (type of bird), if pronounced [kontol], or 'male genitals' if pronounced [konthol]. In data (14) the phrase gunung kembar can be interpreted as 'two similar mountains' or 'woman's breasts'. Both texts deliver a clear message when linked to the overall visual component of the CakCuk design (see data (13) and (14) below).

(13) RAMBATE RATA HAYO
HOLOPIS KONTOL BARIS
BERSATU UNTUK MAJU

RAMBATE RATA HAYO

HOLOPIS KONTOL BARIS

UNITY FOR IMPROVEMENT

(14) Jejak Petualang

EKSPEDISI GUNUNG KEMBAR

TWIN MOUNTAIN EXPEDITION

Adventurer trail
TWIN MOUNT EXPEDITION
TWIN MOUNT EXPEDITION

There are several ways adopted by the CakCuk creator to create simpler texts.

\section{Simplification at a Phonological Level}

At a phonological level, simplification can be implemented by means of dissipation, abbreviation, and acronyms. Below are examples of simplification using each of these three methods.

(a)Simplification by dissipation

(15) kota mesopolitan

SURABAYA KOTA MISUH

Mesopolitan city

SURABAYA SWEARING CITY

(15a) kota misuhpolitan

SURABAYA KOTA MISUH

Misuhpolitan city

SURABAYA SWEARING CITY

Simplification is implemented by the dissipation of a sound unit into a word. The dissipated sound unit consists of one sound or one syllable so the word becomes shorter, as seen in data (15) in the word mesopolitan. Data (15a) is an acronym arranged by substituting one element of a word with another element. The word mesopolitan is the result of substituting the element metro in the word metropolitan with the word misuh 'swearing', thus forming the word mesopolitan by changing the sound $/ \mathrm{i} /$ to $/ \mathrm{e} /$ and $/ \mathrm{u} /$ to $/ \mathrm{o} /$, and dissipating the sound $/ \mathrm{h} /$ in 
the word misuh. The sound change occurs naturally as Surabayan people pronounce high-front and high-back vowels as mid-front and mid-back vowels.

(b) Simplification by abbreviation

(16) NYEGAT BEMO

NAEK ANGKOT, KAMERAD!

ACHTUNG: BEMO LYN X SURABAYA

JURUSAN JOYOBOYO-PASAR WONOKROMO-PABRIK PAKU P.P.

HAIL PUBLIC TRANSPORT

RIDE PUBLIC TRANSPORT, DUDE!

ATTENTION: PUBLIC TRANSPORT SURABAYA X LINE

JOYOBOYO-WONOKROMO MARKET NAIL FACTORY LINE RETURN.

(17) BF Bokep First

The faster way to learn sex

SURABAYA-Tunjungan Centre, Jl. Tunjungan

-Jl. Gentengkali

BF Bokep First

The faster way to learn sex

SURABAYA-Tunjungan Centre, Tunjungan Rd.

Gentengkali Rd.

(18) DTC

DOLLY TRADE CENTER

Pusat Jual Beli

Tukar Tambah "anu” Baru

DTC

DOLLY TRADE CENTER

Trading market

Trade "something" New

(19) C.I.A.

CAK CUK INDONESIA ASLI

Data (16) shows that P.P. is an abbreviation of pulang-pergi (return). Data (17) shows that $J l$. is an abbreviation of jalan (road). Both abbreviations follow the principle of economy. This is completely different from data (18) and (19). Even though these two examples use abbreviations, they do not conform to the principle of economy because the abbreviations are followed by the complete form of what the abbreviation stands for. Simplification by abbreviation is more relevant to the principle of clarity.

(c) Simplification by acronym

(20) KORUPSSI

Di dadaku

Korupssi kebanggaanku

"Kalo terus begini, kapan bisa juara asia"

(apalagi juara dunia....).

\section{KORUPSSI}

In my heart

Korupssi is my glory

"If stays like this, when can we be asian champions"

(let alone world champions)

(21) PERSEBUAYA

SURABAYA

PERSATUAN SEPAK BOLA KOTA BUAYA

PERSEBUAYA

SURABAYA

FOOTBALL UNION OF CROCODILE CITY

(22) INDbONEkSIA

Indonesia

BONEKKA TUNGGAL IKA

Berbeda-beda tetapi tetap bonek juga.

\section{INDbONEkSIA}

Indonesia

BONEKKA TUNGGAL IKA

Different but still bonek

(23) kencing aja bayar seribu rupiah

SURABiAYA

Di Surabaya gak ada yang gratis

Semua butuh biaya di Surabiaya.

Urinating costs a thousand rupiahs

SURABiAYA

In Surabaya nothing is free

Everything costs money in Surabiaya.

Acronyms are created by merging a word with an abbreviation, a word with an acronym, or a word with a word, by inserting a word between the syllables of another word. This yields a new word which is phonetically similar to the word or acronym that is already commonly known. An example of an acronym which merges a word with an abbreviation is the word 
KORUPSSI in data (20); an example of a word merged with an acronym is the word PERSEBUAYA in data (21); and acronyms which merge a word with another word are the words INDbONEkSIA in data (22) and SURABiAYA in (23). Simplification through the use of an acronym may make it hard for the reader to interpret the meaning

\section{Simplification at a Syntactic Level}

Simplification at a syntactic level is carried out by means of reduction, such as pronominal substitution and ellipsis. The following are examples of simplification.

(a) Simplification by substituting pronominal elements

(24) Djembatan Merah

the spirit of never ending hero's legend

LEGENDA KOTA PAHLAWAN

Disaat orang kota lain membakar kotanya sendiri saat diserang musuh atau memindahkan pemerintahannya ke kota lain atau mundur dan bergerilya, orang Surabaya tetap berjuang mempertahankan kehormatannya sampai mati.

Djembatan Merah

the spirit of a never-ending hero's legend HERO CITY LEGEND

While other people burn their city when attacked by enemies, or move their government to another city, or retreat and engage in guerrilla tactics, Surabayans stay fighting for their honour until they die.

(24a) Djembatan Merah

the spirit of never ending hero's legend

LEGENDA KOTA PAHLAWAN

Disaat orang kota lain membakar kotanya sendiri saat diserang musuh atau memindahkan pemerintahannya ke kota lain atau mundur dan bergerilya, orang Surabaya tetap berjuang mempertahankan kehormatan orang Surabaya sampai mati.

Djembatan Merah

the spirit of a never-ending hero's legend

HERO CITY LEGEND

While other people burn their city when attacked by enemies, or move their government to another city, or retreat and engage in guerrilla tactics, Surabayans stay fighting for the Surabayans' honour until they die.
In data (24), -nya is used as a substitute for orang Surabaya, as seen in data (24a). By using this simplification, text (24) is more compact than text (24a).

(b) Simplification by ellipsis

(25) FUCK AMERIKA CUK SURABAYA bentuknya beda, maksudnya sama.

FUCK AMERICA CUK SURABAYA

Different word, same meaning.

(25a) FUCK (umpatan orang) AMERIKA, CUK (umpatan orang) SURABAYA, bentuknya beda, maksudnya sama.

FUCK (swearing by) AMERICANS, CUK (swearing by) SURABAYANS, different word, same meaning

(26) SEMUA MANUSIA BERSAUDARA SEMUA BONEK BERSAUDARA makan di warung gak bayar, naik angkot gak bayar, masuk stadion gak bayar kan semuanya saudara?

ALL PEOPLE ARE BROTHERS

ALL BONEK ARE BROTHERS

eat in restaurants for free, ride public transportation for free, get into the stadium for free, aren't we all brothers?

(26a) SEMUA MANUSIA BERSAUDARA SEMUA BONEK BERSAUDARA

Bonek makan di warung gak bayar, bonek naik angkot gak bayar, bonek masuk stadion gak bayar kan semuanya saudara?

\section{ALL PEOPLE ARE BROTHERS}

ALL BONEK ARE BROTHERS

Bonek eat in restaurants for free, bonek ride public transportation for free, bonek get into the stadium for free, aren't we all brothers?

(27) $100 \%$ CakCuk SOERABAJA

(27a) $100 \%$ CakCuk (asli buatan) SOERABAJA

$100 \%$ Cak-Cuk 
(Originally made in) SOERABAJA

Texts (25)--(27) above are more economic or simpler than (25a)--(27a).

\section{Principle of Expressiveness in CakCuk Discourse}

The principle of expressiveness not only concerned with text efficiency, but also text effectiveness in a broader sense, including expressive and aesthetic communication. This principle is defined in the maxim of iconicity, which encourages the language user to arrange the text by imitating a particular aspect of the message.

(28) SURABAYA TERLOKALISASI INI YANG SALAH SIAPA? YANG SALAH SIAPA INI? SIAPA INI YANG SALAH? SALAH SIAPA YANG INI? SIAPA YANG SALAH INI? YANG INI SALAH SIAPA? INI SIAPA YANG SALAH? KREMIL, KEMBANG KUNING, DOLLY, MORO SENENG, JARAK, BAN SEPUR WONOKROMO, GUBENG POJOK, DR.SUTOMO, STREN DARMO KALI, IRIAN BARAT, BUNDERAN WARU, STREN DARMO KALI, STREN GENTENG KALI, STASIUN TANDES, SIDO KUMPUL, KEDUNG DORO, PATTAYA, BANGUN SARI, DIPONEGORO, BAMBU RUNCING, ROLAK GN SARI, KAWATAN, SENGSENG.

SURABAYA LOCALIZED

WHO SHOULD BE CHARGED? SHOULD BE CHARGED WHO? BE CHARGED SHOULD WHO? CHARGED SHOULD BE WHO? WHO CHARGED SHOULD BE? KREMIL, KEMBANG KUNING, DOLLY, MORO SENENG, JARAK, BAN SEPUR WONOKROMO, GUBENG POJOK, DR.SUTOMO, STREN DARMO KALI, IRIAN BARAT, BUNDERAN WARU, STREN DARMO KALI, STREN GENTENG KALI, STASIUN TANDES, SIDO KUMPUL, KEDUNG DORO, PATTAYA, BANGUN SARI, DIPONEGORO, BAMBU RUNCING, ROLAK GN SARI, KAWATAN, SENG-SENG

(29) DULU DI SURABAYA BANYAK JALAN BERLUBANG-LUBANG SEKARANG
DI SURABAYA BANYAK LUBANG BERJALAN-JALAN

Seng-seng. Bambu Runcing. Diponegoro. Dolly. Moroseneng. Kremil. Jarak. Kenjeran. Rolak Gunungsari. Gn Setan. Ban Sepur Wonokromo. Irian Barat.

A LONG TIME AGO THERE WERE A LOT OF POTHOLES IN SURABAYA. NOWADAYS THERE ARE A LOT OF HOLES WALKING AROUND.

Seng-seng. Bambu Runcing. Diponegoro. Dolly. Moroseneng. Kremil. Jarak. Kenjeran. Rolak Gunungsari. Gn Setan. Ban Sepur Wonokromo. Irian Barat.

(30) koleksi burung terlengkap dan terbesar katanya di kebun binatang wonokromo

tapi yang jelas, pusat makanan "burung" terbesar

se-Asia Tenggara...ya Cuma Dolly

the most complete and biggest bird collection is said

to be at wonokromo zoo

but definitely, the biggest "bird" food market in ASEAN is only Dolly

Data (28) contains a clause which is repeated in various different orders without changing the message. This kind of repetition is clearly not in line with the principle of economy, but it has another rhetoric purpose related to effectiveness and aesthetic communication. This type of repetition is known as expressive repetition, which means the repetition of form for a particular rhetoric purpose, such as creating surprise, impressing the reader, or elevating the reader's interest. In data (29) the clause $B A N Y A K$ $J A L A N$ BERLUBANG-LUBANG and BANYAK $L U B A N G$ BERJALAN-JALAN is not a form of repetition but an example of the application of the principle of expression, which involves comparing two things or two different circumstances while maintaining phonetic similarity. It is a powerful way of showing differences. The same can be seen in data (30), in which the principle of expressiveness is realized through contradiction. The use of this stylistic form in a text makes the speaker more impressed.

The maxim of iconicity can also be realized by presenting a number of aspects of the text in a hyponymic way. This means that there is a correlation 
between the general meaning and the specific meaning. Hyponymic correlation can be seen in the following data.

\section{(31) Dollymart}

One stop sex shopping...

parkir, wisma asyik, jual kondom, R.S. Aids, klinik aborsi, mak erot, pub dangdut, obat kuat panti pijat, tukang sunat, silikon

THE BIGGEST SEX HYPERMARKET

IN SOUTH EAST ASIA

Pusat Pelayanan Sex Terpadu Terbesar di Asean.

Dollymart

One stop sex shopping

Parking, happy house, supply of condoms, Aids hospital, abortion clinic, Mrs Erot, dangdut club, sex drugs, massage, circumcision, silicon THE BIGGEST SEX HYPERMARKET

IN SOUTH EAST ASIA

The biggest integrated sex service in Asean.

The word dollymart in text (31) is superordinate, and other elements such as parkir, wisma asyik, jual kondom, R.S. Aids, klinik aborsi, mak erot, pub dangdut, obat kuat/panti pijat, tukang sunat, and silikon are co-hyponymic. A hyponymic correlation between different sections of the discourse yields a more effective text.

The maxim of iconicity can also be realized through meanings that have associative correlation. For example in data (32) the word donuts possesses associative correlation with roti berlubang, but dolly donuts has semantic correlation with roti berlubang and also associative correlation with another thing that is not mentioned in the text.

\section{(32) DOLLY DONUTS}

ROTI BERLUBANG PALING TERKENAL DI SURABAYA

bisa dimakan di tempat atau dibawa keluar.

\section{DOLLY DONUTS \\ THE MOST FAMOUS HOLED BREAD IN SURABAYA}

Eat in or take away

Aesthetic communication is constructed through units of language that are arranged with consideration to sound alignment or rhyme so that the text creates an aesthetic or poetic impression. Data (33)--(35) below have good aesthetic communication because the text is constructed using rhyme, thus creating a more interesting text.

(33) SURABAYA

SUROBOYO

SURABUAYA kota buaya

kota biaya SURABIAYA

SURABAHAYA KOTA BAHAYA

kota budaya SURABUDAYA

SURABAYA

SUROBOYO

SURABUAYA crocodile city

Fee city SURABIAYA

SURABAHAYA dangerous city

Culture city SURABUDAYA

(34) EL DIAVALO LA DOLLY

DOLLY GHOST

SETAN DOLLY

SURGA DUNIA DI PINTU NERAKA

THE DEVIL THE DOLLY

DOLLY GHOST

DOLLY DEVIL

WORLDLY HEAVEN AT HELL'S DOOR

(35) PERNAH PERGI KE BALI? WAH, BERKALI-KALI

PERNAH MAIN KE DOLI? YAA, BEBERAPA KALI

PERNAH ZIARAH WALI? EHM...LAIN

KALI

HIDUP DI DUNIA CUMA SEKALI, MAS

SEKALI-KALI PERGI ZIARAH WALI

JANGAN CUMA KE BALI, ATAU KE DOLI.

HAVE YOU EVER BEEN TO BALI? YUP, MANY TIMES

HAVE YOU EVER BEEN TO DOLI? YES, SEVERAL TIMES

HAVE YOU EVER BEEN TO WALI'S GRAVE? HMM.. NEXT TIME

YOU LIVE ONLY ONCE, BRO JUST GO TO VISIT WALI'S GRAVE DON'T ONLY GO TO BALI OR TO DOLI

Principles of textual rhetoric and their maxims are not absolute. The creator uses these principles 
and maxims according to the objective he wishes to achieve through the arrangement of the text. The principle of processability is used by the creator in order to emphasize or place focus on the end of the text, despite the fact that this contradicts the principle of economy. The principle of clarity is used by the creator to create a text with a clear message, although at times this contradicts the principle of economy. The principle of economy is used by the creator to make the text simpler without diminishing the message itself, although in order to comply with this, the creator must sacrifice the principle of clarity.

From the explanation about the application of principles of textual rhetoric above, it can be said that the creator of CakCuk needs to pay attention to and take into consideration numerous things related to the stylistic form of the text. By implementing the principle of processability, principle of clarity, and principle of economy, the creator will be able to arrange texts that possess a simple stylistic form, a clear message, and are able to yield efficient transaction. A text with a simple form and a clear message is considered to be insufficient if the text does not have the ability to become an effective and attractive transaction. Therefore, the creator of CakCuk should follow the principle of expressiveness in order to obtain an effective and attractive text.

\section{CONCLUSION}

The creative process of CakCuk involves two kinds of observance of textual rhetoric: first, conformity, in order to fulfil the reader's expectations, and second, violation, in order to emphasize another principle. Both conformity and violation play a part in determining the stylistic form of the text and the power of the discourse yielded by the text.

The stylistic choices related to language use are regulated by principles of textual rhetoric. This can be summarized as four principles: (i) principle of processability, (ii) principle of clarity, (iii) principle of economy, and (iv) principle of expressiveness.

Principles of textual rhetoric and their maxims are not absolute. The creator uses these principles and maxims according to the objective he wishes to achieve through the arrangement of the text. The principle of processability is used by the creator in order to emphasize or place focus on the end of the text, despite the fact that this contradicts the principle of economy. The principle of clarity is used by the creator to create a text with a clear message, although at times this contradicts the principle of economy. The principle of economy is used by the creator to make the text simpler without diminishing the message itself, although in order to comply with this, the creator must sacrifice the principle of clarity. By implementing the principle of processability, principle of clarity, and principle of economy, the creator will be able to arrange texts that possess a simple stylistic form, a clear message, and are able to yield efficient transaction. The creator of CakCuk should follow the principle of expressiveness in order to obtain an effective and attractive text.

\section{REFERENCES}

Brown, Gillian and George Yule (1983). Discourse Analysis. Cambridge: Cambridge University Press.

Grice, H. P. (1981). Logic and Conversation. Syntax and Semantics, 3 Speech Act. New York: Academic Press.

Halliday, M. A. K. and Hasan, Ruqiyah (1979). Bahasa, Teks, dan Konteks: Aspek-Aspek Bahasa dan Semiotik Sosial. Yogyakarta: UGM Press.

Leech, Geoffrey N. (1993). Prinsip-prinsip Pragmatik. Translator: M.D.D. Oka. Jakarta: UI-Press.

Rani, Abdul, Bustanul Arifin, and Martutik (2006). Analisis Wacana: Sebuah Kajian Bahasa dalam Pemakaian. Malang: Bayumedia Publishing.

Slobin, D. I. (1975). The more it changes....on understanding language by watching it moves through time. Paper and Reports on Child Language Development. University of California, Berkeley.

Sudaryanto (1982). Metode Linguistik: Kedudukan, Aneka Jenisnya, dan Faktor Penentu Wujudnya. Yogyakarta: Fakultas Sastra dan Kebudayaan Universitas Gadjah Mada.

Sudaryanto (1985). Metode dan Aneka Teknik Analisis Bahasa. Yogyakarta: Masyarakat Linguistik Indonesia Komisariat Universitas Gadjah Mada.

Sudaryanto (1990). Aneka Konsep Kedataan Lingual dalam Linguistik. Yogyakarta: Duta Wacana University Press.

Sudaryanto (1993). Metode dan Aneka Teknik Analisis Bahasa: Pengantar Penelitian Wahana Kebudayaan secara Linguistik. Yogyakarta: Duta Wacana University Press.

Widdowson, H. G. (1981). Teaching Languages as Communication. Oxford: Oxford University Press. 
Wijana, I Dewa Putu (1995). Wacana Kartun dalam Bahasa Indonesia. Unpublished Dissertation. Pasca Sarjana Universitas Gadjah Mada. Yogyakarta.
Wijana, I Dewa Putu (2003). Wacana Dagadu, Permainan Bahasa, dan Ilmu Bahasa. Pidato Pengukuhan Jabatan Guru Besar pada Fakultas Ilmu Budaya Universitas Gadjah Mada. Yogyakarta. 